\title{
Long-Tailed Pygmy Rice Rats Modify Their Behavioural Response and Faecal Corticosterone Metabolites in Response to Culpeo Fox but Not to Lesser Grison
}

\author{
María del Carmen Hernández ${ }^{1, * \mathbb{D}}$, André V. Rubio ${ }^{2, *(\mathbb{D})}$ and Isabel Barja ${ }^{1,3}$ (D) \\ 1 Departamento de Biología, Campus Universitario de Cantoblanco, Universidad Autónoma de Madrid, \\ C/Darwin 2, 28049 Madrid, Spain; isabel.barja@uam.es \\ 2 Departamento de Ciencias Biológicas Animales, Facultad de Ciencias Veterinarias y Pecuarias, Universidad \\ de Chile, Santa Rosa 11735, La Pintana, Santiago 8820808, Chile \\ 3 Centro de Investigación en Biodiversidad y Cambio Global (CIBC-UAM), Campus Universitario de \\ Cantoblanco, Universidad Autónoma de Madrid, C/Darwin 2, 28049 Madrid, Spain \\ * Correspondence: mariacarmen.hernandez@uam.es (M.d.C.H.); arubio@uchile.cl (A.V.R.)
}

check for updates

Citation: Hernández, M.d.C.; Rubio, A.V.; Barja, I. Long-Tailed Pygmy Rice Rats Modify Their Behavioural Response and Faecal Corticosterone Metabolites in Response to Culpeo Fox but Not to Lesser Grison. Animals 2021, 11, 3036. https://doi.org/ 10.3390/ani11113036

Academic Editors: Marco Apollonio and Nadja Wielebnowski

Received: 15 July 2021

Accepted: 21 October 2021

Published: 22 October 2021

Publisher's Note: MDPI stays neutral with regard to jurisdictional claims in published maps and institutional affiliations.

Copyright: (c) 2021 by the authors. Licensee MDPI, Basel, Switzerland. This article is an open access article distributed under the terms and conditions of the Creative Commons Attribution (CC BY) license (https:/ / creativecommons.org/licenses/by/ $4.0 /)$.
Simple Summary: Prey species must fine-tune their antipredator responses to survive, but also to achieve a positive net energy balance which will enhance biological fitness. Given this, we investigated if Oligoryzomys longicaudatus would adapt their behavioural and physiological antipredator responses depending on their relative presence in the predator's diet. By exposing this rodent species to culpeo fox and lesser grison faeces, we found that $O$. longicaudatus behavioural and physiological strategies were modulated depending on the predator's diet. Specifically, rodents would trigger their antipredator responses in the presence of the most dangerous predator, the culpeo, which consumes a higher proportion of $O$. longicaudatus compared to the lesser grison. Our findings could be of importance for the development of more humane and efficient strategies to control rodent populations.

Abstract: Even though behavioural and physiological reactions to predation risk exhibited by prey species have received considerable attention in scientific journals, there are still many questions still unsolved. Our aim was to broaden the knowledge on one specific question: do long-tailed pygmy rice rats adapt their behavioural and physiological antipredator strategies depending on the predator species? For this question, we live-trapped in a temperate forest in Southern Chile long-tailed pygmy rice rats (Oligoryzomys longicaudatus), which were exposed to three predator odour phases (Phase 0: preliminary, no predator cues; Phase 1: one plot with culpeo fox faeces (Lycalopex culpaeus), one plot with lesser grison (Galictis cuja) faeces and one plot acting as a control with no odour; Phase 2: post treatment, no predator cues). We measured the behavioural response by the capture ratio. To assess the physiological stress response, we collected fresh faecal samples to quantify faecal corticosterone metabolites (FCM). Our results showed that O. longicaudatus increased both the capture ratio and FCM levels in the presence of culpeo cues. Culpeo foxes have higher densities in the study area than G. cuja and exhibit a higher activity pattern overlap with O. longicaudatus. Moreover, it has been also been reported in other regions that $L$. culpaeus consumption of $O$. longicaudatus is more frequent compared to G. cuja diet. The increase in capturability could be because traps can be regarded as a shelter in high-risk settings, but it can also be explained by the predator inspection behaviour. The increase in FCM concentrations during culpeo treatment can be linked to the adaptive mobilisation of energy to execute antipredator responses to increase survival chances.

Keywords: predator cues; predation risk; Oligoryzomys longicaudatus; Lycalopex culpaeus; Galictis cuja; glucocorticoids; corticosterone

\section{Introduction}

Predation risk drives the evolution of numerous prey adaptations [1,2]. There exists a vast variety of responses; in particular, behavioural and physiological adaptations are key 
to cope with predator pressure [3-5]. Among rodents, the most common behavioural responses to predation risk are linked to changes in daily activity patterns, use of space, social behaviour and feeding habits [6-8]. In particular, previous studies have demonstrated that the presence of direct predator cues can prompt individuals to avoid those areas because the perceived predation risk is higher $[3,9,10]$. However, previous field studies using live trapping to measure predator avoidance have also found that rodents could consider traps as shelter in the presence of predator cues [11].

The physiological stress response is a highly refined neuroendocrine-systemic pathway that plays a major role in the ability of animals to overcome changes in the environment $[12,13]$, including predation risk. In particular, it is a crucial process to increase the energy available to the individual [14] to escape from predators. When the prey detects the presence of the predator, the stimulus triggers the activation of the hypothalamicpituitary-adrenal axis (HPA) axis, increasing the secretion and release of glucocorticoids (GC) by the adrenal gland [15] and leading to the mobilization of reserves needed to deal with the predatory event [12,16]. Whereas the short-term release of GC is an adaptive response which enhances the probability of surviving by redirecting energy from non-vital processes [14,17], a sustained release of GC can produce severe deleterious effects (such as immune suppression and endocrine disruption), leading to a critical reduction in biological fitness $[12,14,18]$.

Despite predation risk assessment in prey species having been widely addressed in the literature, numerous aspects of these adaptive strategies remain unclear. For example, how predator species which exhibit marked differences in density, activity patterns and diet can affect the antipredator strategies of such prey species.

In this study, we analysed the behavioural and physiological responses of Oligoryzomys longicaudatus to two predators which show different activity patterns, densities and dietary preferences. On the one hand, the culpeo fox seems to be more abundant in the study area [19] and their daily activity patterns are cathemeral, exhibiting intermittent activity throughout the $24 \mathrm{~h}$ cycle [19]. In other regions, the culpeo fox has been described as a facultative trophic specialist mainly feeding on rodents and lagomorphs, depending on local abundances [20,21]. O. longicaudatus can be an importance source of food for this species in Chilean ecosystems [22,23] as high densities of this prey can be found in central and southern temperate forests $[24,25]$. On the other hand, the lesser grison appears to be scarce in the study area compared to fox abundance [19]. This species primarily feeds on rodents and lagomorphs [26,27], but $O$. longicaudatus do not represent an important fraction of their diet in central and southern Chile [26,28,29]. Moreover, lesser grisons have been reported to be mainly diurnal and crepuscular $[30,31]$ and camera trapping records confirmed that lesser grisons in the area are mostly diurnal [19], while O. longicaudatus is chiefly considered nocturnal [32-34].

The aim of this study was to evaluate the behavioural and physiological stress responses (through capture ratios and faecal corticosterone metabolite levels, respectively) of $O$. longicaudatus to two different predators (culpeo and lesser grison) that differ in their daily activity patterns, abundance and diet. According to the risk allocation hypothesis [35], we expected that $O$. longicaudatus would increase their antipredator efforts when perceived predation risk was higher (i.e., in the presence of culpeo cues, because they pose a greater threat for O. longicaudatus than the lesser grison). Therefore, we predicted a lower capture ratio and an increased GC release in rodents exposed to culpeo cues.

\section{Materials and Methods}

\subsection{Study Area}

The study was conducted in a temperate forest located in Huelemolle, at the Villarrica lake basin $\left(39^{\circ} 16^{\prime} \mathrm{S}, 71^{\circ} 48^{\prime} \mathrm{W}\right)$, Araucanía Region (southern Chile). The climate in this area is temperate-humid with a short dry season ( $<4$ months) in summer (January-March) and an average rainfall of $2000 \mathrm{~mm}$ distributed throughout the year. Minimum and maximum temperatures range from $10.4^{\circ} \mathrm{C}$ to $25.3^{\circ}$, respectively, in the warmest month 
(January) and $4.2{ }^{\circ} \mathrm{C}$ to $12.1{ }^{\circ} \mathrm{C}$ in the coldest month (July). The vegetation comprises forests dominated by Patagonian oak (Lophozonia obliqua) and coigue (Nothofagus dombeyi), mainly associated with Chilean laurel (Laurelia sempervirens), olivillo (Aextoxicon punctatum), ulmo (Eucryphia cordifolia) and lingue (Persea lingue) (Gajardo 1993). Carnivore species found in the area include puma (Puma concolor), chilla fox (Lycalopex griseus), molina's hognosed skunk (Conepatus chinga), güiña (Leopardus guigna), culpeo fox (Lycalopex culpaeus) and lesser grison (Galictis cuja) [36,37]. Rodent species found in the study area include O. longicaudatus (71.5\%), Abrothrix longipilis (11.4\%), Rattus rattus (10.6\%) and Abrothrix olivaceus $(6.5 \%)$, during autumn and winter [A. Rubio, unpublished data].

\subsection{Experimental Design}

Live-trapping was performed during the austral winter (June 2019), when O. longicaudatus reaches peak abundances in temperate forests $[38,39]$. The study area was divided into three plots (A/B/C) $200 \mathrm{~m}$ apart from each other in order to avoid pseudoreplication (i.e., capturing the same mouse in two different plots). In each plot, we placed 42 Sherman-like traps $(240 \times 80 \times 90 \mathrm{~mm}$; Schulz Instruments, Santiago, Chile) in a $6 \times 7$ grid, with $5 \mathrm{~m}$ of distance among them $[40,41]$. Traps were activated at dusk and checked daily at dawn. All traps were placed under vegetation to buffer extreme environmental conditions.

The experiment was divided into three different and consecutive phases: phase 0 (preliminary), phase 1 (treatment) and phase 2 (post treatment). Each phase took place over 3 consecutive days. During phase 0 , no carnivore faecal odour was placed in any plot in order to determine the basal behavioural and physiological responses of $O$. longicaudatus. In phase 1, one plot (A) was used as a control with no experimentally added carnivore faecal odour and the other two plots were subjected to carnivore faecal odour: one plot (B) with culpeo fox faeces (L. culpaeus) and one plot (C) with lesser grison (G. cuja) faeces. In this phase, $10 \mathrm{~g}$ of faecal material (see section simulation of predation risk by faecal odour) was placed outside each trap. Finally, in phase 2, we removed the faecal material on the first day, in order to evaluate the effect of the decrease in predation risk over time. All traps during the three study phases were baited with rolled oats with vanilla essence.

\subsection{Simulation of Predation Risk by Faecal Odour}

Culpeo fox and lesser grison faeces were used to simulate predation risk because they are two common O. longicaudatus predators [23,41]. In general, both fox and mustelid faeces and urine have been demonstrated to successfully trigger antipredatory responses in wild rodents $[10,11,42,43]$. Faeces were gathered from captive adult animals ( 2 males and 2 females for both culpeo and lesser grison) from the Metropolitan Zoo (Santiago, Chile). All animals were on a carnivorous diet and we only collected fresh scats, i.e., only those with a layer of mucus, an elevated level of hydration and strong odour [44,45]. All faeces samples were frozen at $-20{ }^{\circ} \mathrm{C}$ until treatment preparation. Due to the fact that volatile compounds can vary depending on the season or individual factors [46-48], all faeces were mixed to provide a homogeneous stimulus across all treated traps. Faecal material was replaced every day at sunset to ensure correct odour effectiveness.

\subsection{Data Collection}

Each captured individual was identified to the species level based on external morphology. Sex was determined using the anal-genital distance, which is longer in males than in females [49]. In the same way, reproductively active females were classified on the basis of the presence of prominent nipples and perforated vaginal membranes, whereas reproductive active males were identified due to the increased size of their testicles, that usually descend into the scrotal sac [49]. Body mass was measured employing a $50 \mathrm{~g}$ hand-held scale (PESOLA, $50 \mathrm{~g}$ ). All captured animals were marked on specific body areas (paws, inner ear area, tail) with harmless waterproof paints to identify possible recaptures in each phase and to avoid pseudoreplication. After handling, animals were released at their place of capture. 


\subsection{Faeces Collection and Quantification of Faecal Corticosterone Metabolites}

Quantifying faecal cortisol/corticosterone metabolites has proven to be a reliable non-invasive method to measure GC levels in wild species [8,11,50-52]. Since circadian rhythms can produce differences in excretion patterns [53], we gathered faecal samples each day at the same time in the mornings (between 8:00-10:00 a.m.). Faeces contaminated with urine were not collected to avoid any possible cross contamination [53]. In the field, faecal samples were stored in Eppendorf tubes in a portable cooler with wet ice $\left(4^{\circ} \mathrm{C}\right)$, later (around 12:00 a.m.), after data collection, all samples were stored at $-20^{\circ} \mathrm{C}$. Faecal glucocorticoid extraction was performed following the protocol of Barja et al. [50] and Navarro-Castilla et al. [43]. First, frozen faecal samples were dried in the laboratory oven at $90{ }^{\circ} \mathrm{C}$ for $4 \mathrm{~h}$. Then, $0.05 \mathrm{~g}$ of each sample was weighed and mixed it with $500 \mu \mathrm{L}$ of $80 \%$ methanol and $500 \mu \mathrm{L}$ of phosphate buffer. Eppendorfs were vortexed by hand for $15 \mathrm{~s}$ and then multivortexed for $16 \mathrm{~h}$. After that, the samples were centrifuged for $15 \mathrm{~min}$ at $2500 \times \mathrm{g}$. FCM quantification was performed using a commercial corticosterone enzyme immunoassay kit (DEMEDITEC Diagnostics $\mathrm{GmbH}$, Kiel, Germany; corticosterone: DEMEDITEC D24145) to determine the faecal metabolite hormone levels by the same procedure published in previous studies $[10,11,43]$. The corticosterone kit was validated by determining the parallelism, precision and accuracy: Parallel displacement curves were obtained by comparing serial dilutions $(1: 32,1: 16,1: 8,1: 4,1: 2,1: 1)$ of pooled faecal extracts with the standard curves, resulting in both curves being parallel. Precision was tested through intra- and inter-assay coefficients of variation for faecal samples, and the corticosterone intra-assay coefficient of variation was $8.7 \%$ and inter-assay was $9.3 \%$. The mean recovery (accuracy) percentage from the assayed hormone was $92.7 \%$. Results are expressed as nanograms of corticosterone metabolites per gram of dry faeces matter.

The long-tailed pygmy rice rat is one of the main reservoirs of Hantavirus in Chile, which entails a high risk of transmission when animals are kept in captivity. Therefore, the authors did not perform an ACTH challenge to avoid unnecessary health risks, and since the required permits to keep this species in the laboratory would only be granted under strictly justified conditions. In addition, the physiological validation clearly supports that the kit used was correctly measuring corticosterone levels in the faecal samples. Considering that during the treatment all individuals were exposed during 3 days to the same continuous stressor (predators' faeces), we consider that the ACTH was not strictly required. Furthermore, this minimizes unnecessary animal suffering and, thus, we carried out a non-invasive procedure.

\subsection{Statistical Analysis}

To analyse the behavioural response of $O$. longicaudatus to predation risk, we conducted a generalized linear model (GLM) using capture frequency (capture vs no capture) as a response variable in a model with binary distribution and logit as the link function. We included as explanatory variables the predation risk treatment (Phase 0 (Preliminary)/Phase 1 (Control)/Phase 1 (Culpeo)/Phase 1 (Lesser grison)/Phase 2 (Post treatment), and the plot $(\mathrm{A} / \mathrm{B} / \mathrm{C})$. Even though the selected plots were similar in vegetation composition and percentage of canopy cover (A. Rubio, unpublished data), we wanted to control for its possible effects.

We conducted a generalized linear mixed model (GLMM) with gaussian distribution and identity link to analyse the physiological stress response of $O$. longicaudatus. Logtransformed FCM levels were set as the response variable for the model. Explanatory variables considered in the model were the predator treatment (Phase 0 (Preliminary)/Phase 1 (Control)/Phase 1 (Culpeo)/Phase 1 (Lesser grison)/Phase 2 (Post treatment) and the sex (female/male). The individual was set as a random effect to control for its possible effect. Model selection was based on Akaike Information Criterion (AIC).

Sex and reproductive status have been previously described as being able to modulate rodents' physiological stress response to predation risk $[8,10,11,43]$. To control for its possible effects, we included sex as a fixed effect in the models. Reproductive status was 
not considered in the analyses because all individuals captured were not breeding. For both models, post hoc comparison was performed using the Mann-Whitney U test.

The software used to perform the statistical analysis were SPSS 23.0 for Windows (SPSS Inc., Chicago, IL, USA) and R 4.1.1 (http:/ / www.r-project.org) for the GLMM. Data are represented as mean \pm standard error (SE). Results were considered significant at $\alpha<0.05$.

\section{Results}

\subsection{Behavioural Response: Capturability}

The total number of O. longicaudatus captures in this study was 299 , corresponding to 88 different individuals. Since trapping efforts were not the same for each treatment, we corrected each number of captures for the corresponding trapping effort in traps-night (Figure 1). A total of 121 of the captures were made under preliminary treatment (total trapping effort for control traps was 378), 24 captures corresponded to control treatment (trapping effort was 126), 46 corresponded to culpeo treatment (trapping effort 126), 34 corresponded to lesser grison treatment (trapping effort 126), and 74 to the post treatment (trapping effort 378). Results of the GLM analysing the capture ratio (Table 1), showed that there were statistically significant differences in capture probability depending on the predation risk treatment (Figure 1), with the culpeo treatment being the one with the highest capturability. Post hoc testing with the Mann-Whitney U test revealed statistically significant differences between preliminary and post treatment $(p<0.005)$ and culpeo fox and post treatment $(p<0.0001)$.

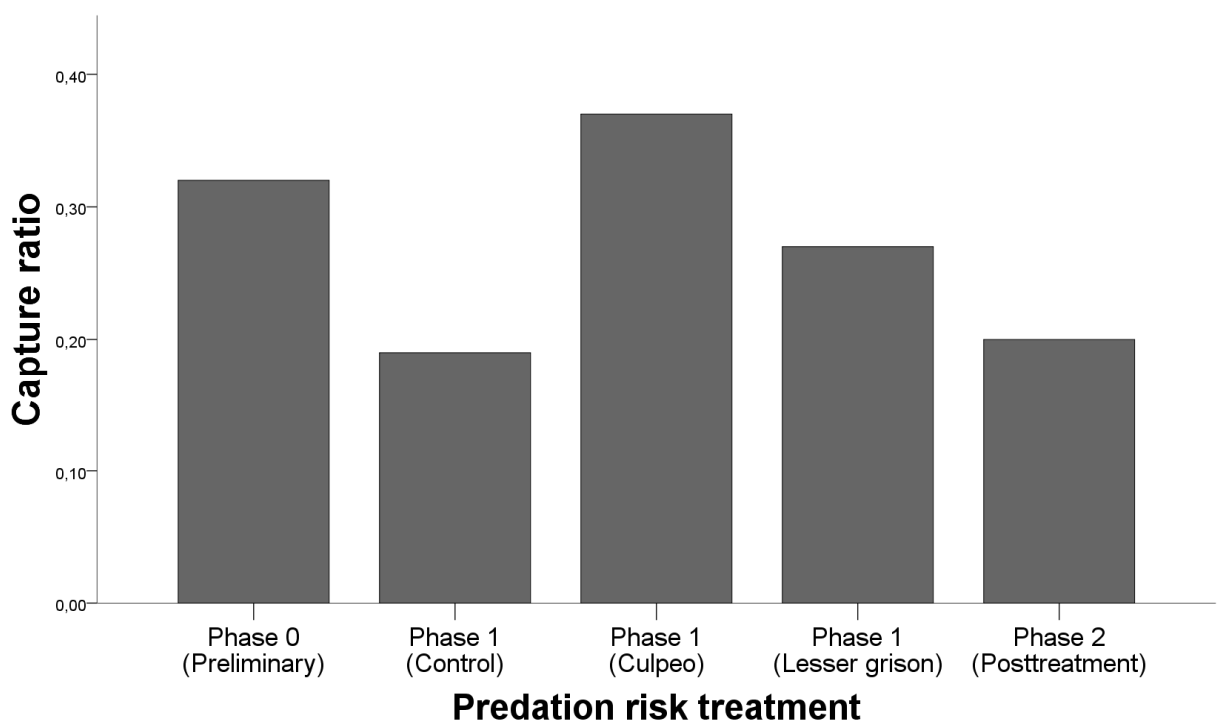

Figure 1. Capture ratio (number of captures of $O$. longicaudatus corrected by the trapping effort in traps-night) depending on the predation risk treatment (Phase 0-Preliminary/Phase 1Control/Phase 1-Culpeo/Phase 1-Lesser grison/Phase 2-Post treatment).

Table 1. Results of the GLM, analysing the effects of experimental and environmental factors on O. longicaudatus capturability.

\begin{tabular}{cccc}
\hline Effect & $\boldsymbol{F}$ & df & $p$-Value \\
\hline Intercept & 160.70 & 1 & $<0.001$ \\
Predation risk treatment & 18.94 & 4 & $<0.001$ \\
Plot & 3.75 & 2 & 1.153 \\
\hline
\end{tabular}

\subsection{Physiological Stress Response}

Results of the GLMM analysing the individual and external factors which modulated O. longicaudatus FCM levels are shown in Table 2. The predation risk treatment was the only explanatory variable responsible for the variation in the FCM levels. The highest mean FCM levels were found during Phase 1 culpeo treatment (Figure 2), followed by Phase 1 
controls. The lowest FCM concentrations were detected in O. longicaudatus captured during Phase 0 (preliminary), followed by Phase 1 lesser grison treatment and Phase 2 (post treatment). The Mann-Whitney U post hoc test demonstrated that differences between groups were found between the culpeo and preliminary treatments $(p<0.05)$, culpeo and post treatment $(p<0.05)$ and between the culpeo and lesser grison treatments $(p<0.05)$.

Table 2. Results of the GLMM, analysing the effect of experimental and environmental factors on O. longicaudatus faecal corticosterone metabolite levels.

\begin{tabular}{cccccc}
\hline Effect & Estimate & $\begin{array}{c}\text { Std. } \\
\text { Error }\end{array}$ & df & $\boldsymbol{t}$ Value & $\boldsymbol{p}$-Value \\
\hline Intercept & 11.25 & 0.07 & 103.90 & 152.39 & $<0.001$ \\
Treatment-Control & 0.10 & 0.11 & 247.98 & 0.88 & 0.3817 \\
Treatment-Culpeo & 0.38 & 0.10 & 262.49 & 3.65 & $<0.001$ \\
Treatment-Lesser grison & 0.04 & 0.11 & 262.05 & 0.39 & 0.699 \\
Treatment-Posttreatment & 0.04 & 0.09 & 249.97 & 0.47 & 0.639 \\
Sex-Male & 0.11 & 0.07 & 57.24 & 1.53 & 0.132 \\
\hline
\end{tabular}

Random factor (Individual): variance: 0.0059; std dev: 0.0766 .

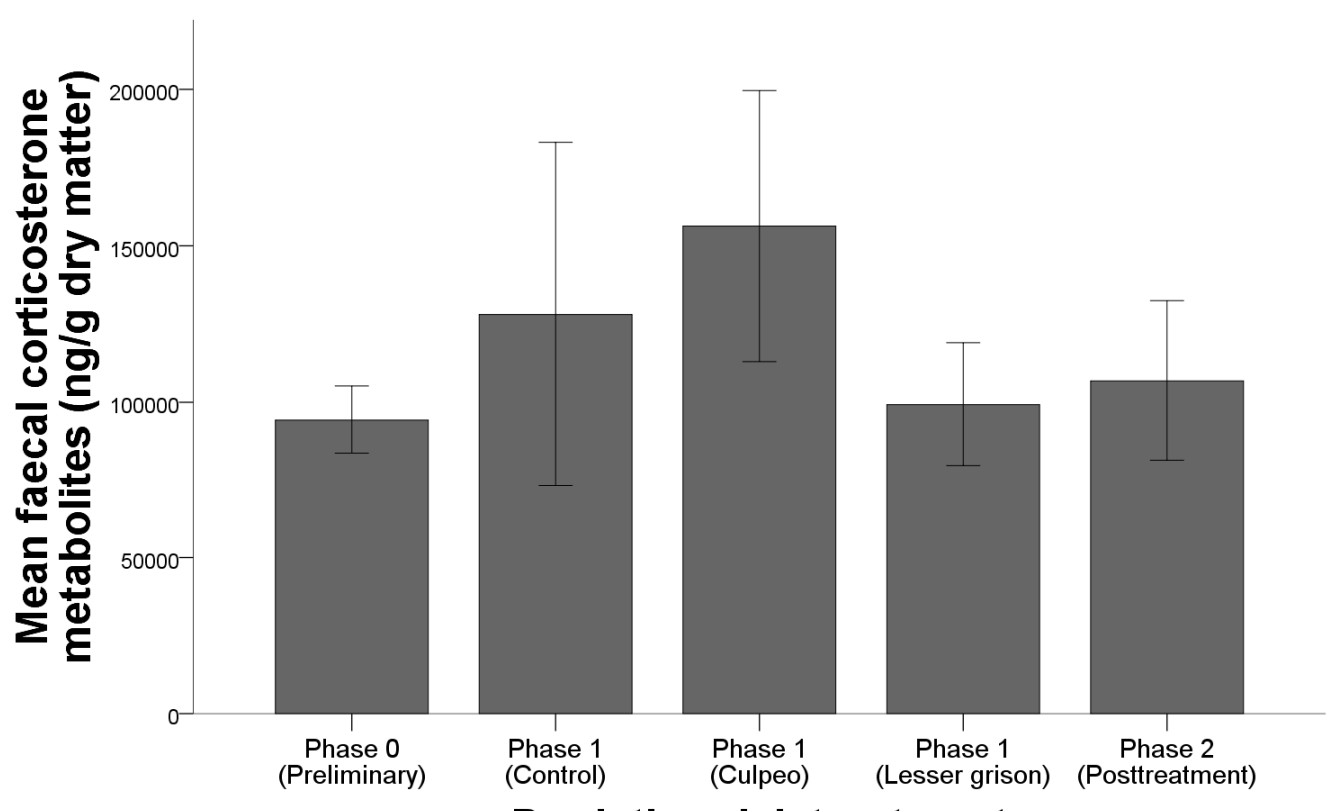

Predation risk treatment

Figure 2. Mean faecal corticosterone metabolite levels of $O$. longicaudatus depending on the predation risk treatment (Phase 0 -Preliminary/Phase 1 -Control/Phase 1 -Culpeo/Phase 1-Lesser grison/Phase 2-Post treatment).

\section{Discussion}

\subsection{Behavioural Response}

It has been described that predator faeces can cause an avoidance effect in many small mammal species (e.g., Apodemus sylvaticus, Microtus agrestis, Myodes glareolus, Arvicola amphibius, Oryctolagus cuniculus and so forth) [10,43,54-56]. However, in our study, O. longicaudatus capturability increased during the culpeo fox treatment while the lowest capture ratio was found during the control treatment and the post treatment. Previous studies have also suggested that rodents can regard traps as a suitable shelter under increased risk of predation [11], as the benefits of finding a safe spot to hide outweigh the risks taken by exploring these unknown devices. Given this, O. longicaudatus may have used traps as a refuge during the culpeo treatment (which could explain the increase in rodent capturability), as it was the most dangerous scenario compared to the other ones. Another possible explanation would be the "predator inspection" phenomenon, which suggests 
that prey approach the predator cues to extract information and to improve their risk assessment [57-59].

Chemically-mediated predator avoidance may be modulated by the predator's diet, as volatile composition of predator by-products would be different depending on the food ingested [5,60-63]. In this study, behavioural antipredator response to lesser grison treatment could have not been triggered because lesser grison is not one of the main predators of $O$. longicaudatus; thus, the perceived risk was lower, so it could be more optimal to not divert so much time and energy from other vital activities [35].

Moreover, previous studies have suggested that faeces of carnivores that defecate in latrines could provide less valuable information for predation risk assessment, as their scats are only concentrated in certain spots of their territory $[8,54,64,65]$; thus, they do not accurately reflect the predator's presence or movement patterns. Since lesser grisons defecate in latrines $[29,66]$, it might be possible that the uncertain benefits of triggering the antipredator responses in this setting would not counterbalance the costs for O. longicaudatus.

In the case of the post treatment, capturability could have been lower because rodents were not under an immediate predator threat, so they were not compelled to seek shelter. In the first phase, capturability was higher than the post treatment, which could be because traps were novel objects and $O$. longicaudatus could have been exploring these devices to assess their risks [67-69]. O. longicaudatus is considered a scansorial species [70] but it frequently forages on the ground and explores novel sources of food [71]. They possess a remarkable jumping ability and partial bipedalism, which allow them to escape quickly from predators when they are foraging on the ground [72,73].

The post-hoc test was unable to detect statistically significant differences involving the control treatment, probably due to the small sample size of this treatment compared to the preliminary and post treatment.

\subsection{Physiological Stress Response}

Despite several studies failing to corroborate the activation of the HPA axis of rodent species under predation risk $[8,43,74]$, our results were in accordance with studies that reported a significant glucocorticoid release in the presence of predator cues $[10,11,75]$.

We found that HPA axis activation of $O$. longicaudatus was higher during culpeo treatment. As we expected, rodents triggered the glucocorticoid release when facing the most threatening treatment (i.e., culpeo cues), which would allow prey to mobilize energy towards the organs and tissues where it is needed to display successful antipredator strategies (e.g., flight, finding shelter, defensive attack), and thus, survive [76,77]. Even though rodents could have felt safe inside traps, once they were caught, they were continuously exposed to fox faeces (which were next to the entrance of the trap), and this may have triggered and maintained a higher physiological antipredator response [10,11]. As for the lesser grison treatment, it seems that the threat it posed was not enough to activate the HPA axis. As we mentioned before, lesser grison is scarce in the study area [19], and they have different active periods (O. longicaudatus is nocturnal while lesser grisons are mostly diurnal) [19]. Moreover, studies conducted in other regions showed that O. longicaudatus is not an important part of the lesser grison diet, [26,28,29]. Therefore, the costs of displaying this physiological antipredator strategy could surpass the possible benefits obtained, and hence, it would not be adaptive to increase GC production. Since there are no studies on the diet of mesocarnivores in the area, future studies would be needed to confirm the importance of the differential consumption of the target prey species in the modulation of the antipredator responses. Additionally, the fact that lesser grisons defecate in latrines could also explain the absence of the HPA response, as the information provided in those faeces could be not sufficiently reliable $[8,54,64,65]$. These findings would be also explained by the threat sensitivity hypothesis $[78,79]$, which explains that prey would assess the current risk in each different context and would differentially respond depending on the degree of perceived risk. Threat sensitivity hypothesis has been previously corroborated in small mammal species such as A. sylvaticus [11] and O. cuniculus [80]. 
Moreover, FCM levels decreased to baseline levels once the riskier predator treatment (i.e., culpeo cues) was removed. The physiological stress response is an energy-expensive pathway, so it appears that it would be more energy efficient and fitness-enhancing to arrest such a response once the predator has dispersed. This result would be in accordance with the optimality theory [81-83], which proposes that natural selection would favour certain optimal evolutionarily stable phenotypes because they outperform others, and thus would bring higher fitness to those individuals. Nonetheless, future studies focused on the analysis of this effect would be needed to confirm when exactly FCM levels drop, as lesser grison treatment was apparently unable to trigger the physiological antipredator response.

\section{Conclusions}

Taken together, our findings provide a new insight into the trade-offs involved in rodents' risk assessment. Individuals triggered the physiological antipredator response only in the presence of the predator which shows a higher density, activity overlap and consumption of $O$. longicaudatus (i.e., culpeo fox), and thus poses a bigger threat. On the contrary, O. longicaudatus did not allocate energy to these strategies in the presence of predator cues of lesser grison, which is mainly diurnal, not abundant in the area and does not regularly consume $O$. longicaudatus. Moreover, following energy optimization principles, the physiological stress response of $O$. longicaudatus faded to baseline levels after the encounter with the most dangerous predator. These results could be of critical importance not only in contributing to a better understanding of animal ecophysiology, behaviour and the adaptive strategies displayed by prey but also for the management and conservation of wildlife populations (e.g., rodent control strategies compatible with biodiversity conservation).

Author Contributions: Conceptualisation and study design, A.V.R., I.B., M.d.C.H.; methodology, I.B., A.V.R.; fieldwork, A.V.R., M.d.C.H.; laboratory analysis, I.B., M.d.C.H.; validation: I.B.; statistical analyses: M.d.C.H.; supervision: I.B.; writing—original draft preparation, M.d.C.H.; writing—review and editing, I.B., A.V.R., M.d.C.H.; funding acquisition, A.V.R., I.B. All authors have read and agreed to the published version of the manuscript.

Funding: This research was funded by ANID/FONDECYT Initiation NO. 11180631 from the National Research and Development Agency (ANID). AVR was supported by ANID + PAI Convocatoria Nacional de Subvención a la Instalación en la Academia 2018 NO. PAI77180009.

Institutional Review Board Statement: The study was conducted according to the guidelines of the Declaration of Helsinki and all procedures of animal sampling were approved by the Servicio Agrícola y Ganadero (SAG) under permit NO. 7479/2018, and by the Institutional Animal Care and Use Committee (University of Chile, Bioethical approval NO. 18197-VET-UCH).

Informed Consent Statement: Not applicable.

Data Availability Statement: Not applicable.

Acknowledgments: We thank Basilio Lucero and Esteban Vásquez for their assistance during field sampling, and Tomás Ibarra for logistical support in the field. Many thanks also to Rodrigo Salgado for his invaluable help with the R software. We are grateful to the staff of the Metropolitan Zoo for providing us the faecal samples of their captive carnivores. We would also want to thank the landowners for granting us permission to perform this research on their lands.

Conflicts of Interest: The authors declare no competing interests.

\section{References}

1. Abrams, P.A. The Evolution of Predator-Prey Interactions: Theory and Evidence. Annu. Rev. Ecol. Syst. 2000, 31, 79-105. [CrossRef]

2. Johnson, J.B.; Belk, M.C. Predators as Agents of Selection and Diversification. Diversity 2020, 12, 415. [CrossRef]

3. Barbosa, P.; Castellanos, I. Ecology of Predator-Prey Interactions; Oxford University Press: Oxford, UK, 2005.

4. Davies, N.B.; Krebs, J.R.; West, S.A. An Introduction to Behavioural Ecology; John Wiley \& Sons: Hoboken, NJ, USA, 2012.

5. Scherer, A.E.; Smee, D.L. A review of predator diet effects on prey defensive responses. Chemoecology 2016, 26, 83-100. [CrossRef] 
6. Lima, S.L. Nonlethal effects in the ecology of predator-prey interactions. Bioscience 1998, 48, 25-34. [CrossRef]

7. Sánchez-González, B.; Barja, I.; Navarro-Castilla, Á. Wood mice modify food intake under different degrees of predation risk: Influence of acquired experience and degradation of predator's faecal volatile compounds. Chemoecology 2017, 27, 115-122. [CrossRef]

8. Navarro-Castilla, A.; Barja, I.; Diaz, M. Foraging, feeding, and physiological stress responses of wild wood mice to increased illumination and common genet cues. Curr. Zool. 2018, 64, 409-417. [CrossRef]

9. Hayes, R.A.; Nahrung, H.F.; Wilson, J.C. The response of native Australian rodents to predator odours varies seasonally: A by-product of life history variation? Anim. Behav. 2006, 71, 1307-1314. [CrossRef]

10. Sanchez-Gonzalez, B.; Planillo, A.; Navarro-Castilla, A.; Barja, I. The concentration of fear: Mice's behavioural and physiological stress responses to different degrees of predation risk. Naturwissenschaften 2018, 105, 16. [CrossRef] [PubMed]

11. Hernández, M.C.; Navarro-Castilla, Á.; Planillo, A.; Sánchez-González, B.; Barja, I. The landscape of fear: Why some free-ranging rodents choose repeated live-trapping over predation risk and how it is associated with the physiological stress response. Behav. Process. 2018, 157, 125-132. [CrossRef]

12. Romero, L.M. Physiological stress in ecology: Lessons from biomedical research. Trends Ecol. Evol. 2004, 19, 249-255. [CrossRef]

13. Casas, F.; Benítez-López, A.; Tarjuelo, R.; Barja, I.; Viñuela, J.; García, J.T.; Morales, M.B.; Mougeot, F. Changes in behaviour and faecal glucocorticoid levels in response to increased human activities during weekends in the pin-tailed sandgrouse. Sci. Nat. 2016, 103, 91. [CrossRef] [PubMed]

14. Sapolsky, R.M.; Romero, L.M.; Munck, A.U. How do glucocorticoids influence stress responses? Integrating permissive, suppressive, stimulatory, and preparative actions. Endocr. Rev. 2000, 21, 55-89.

15. Barton, B.A. Stress in fishes: A diversity of responses with particular reference to changes in circulating corticosteroids. Integr. Comp. Biol. 2002, 42, 517-525. [CrossRef]

16. Bonier, F.; Martin, P.R.; Moore, I.T.; Wingfield, J.C. Do baseline glucocorticoids predict fitness? Trends Ecol. Evol. 2009, 24, 634-642. [CrossRef] [PubMed]

17. Wingfield, J.C.; Romero, L.M. Adrenocortical responses to stress and their modulation in free-living vertebrates. Compr. Physiol. 2010, 23, 211-234.

18. Stewart, P.M.; Krone, N.P. The adrenal cortex. In Williams Textbook of Endocrinology; Larsen, P.R., Kronenberg, H., Melmed, S., Polonsky, K.S., Eds.; Saunders: Philadelphia, PA, USA, 2003.

19. Gálvez, N.; Meniconi, P.; Infante, J.; Bonacic, C. Response of mesocarnivores to anthropogenic landscape intensification: Activity patterns and guild temporal interactions. J. Mammal. 2021, 102, 1149-1164. [CrossRef]

20. Lantschner, M.V.; Rusch, V.; Hayes, J.P. Habitat use by carnivores at different spatial scales in a plantation forest landscape in Patagonia, Argentina. Ecol. Manag. 2012, 269, 271-278. [CrossRef]

21. Guntiñas, M.; Lozano, J.; Cisneros, R.; Malo, A.F. Ecology of the culpeo (Lycalopex culpaeus): A synthesis of existing knowledge. Hystrix 2021, 32. [CrossRef]

22. Zúñiga, A.; Muñoz-Pedreros, A.; Fierro, A. Dieta de Lycalopex griseus (Gray, 1837)(Mammalia: Canidae) en la depresión intermedia del sur de Chile. Gayana 2008, 72, 113-116. (In Spanish) [CrossRef]

23. Zúñiga, A.H.; Fuenzalida, V. Dieta del zorro culpeo (Lycalopex culpaeus Molina 1782) en un área protegida del sur de Chile. Mastozoología Neotrop. 2016, 23, 201-205. (In Spanish)

24. Moreira-Arce, D.; Vergara, P.M.; Boutin, S.; Simonetti, J.A.; Briceño, C.; Acosta-Jamett, G. Native forest replacement by exotic plantations triggers changes in prey selection of mesocarnivores. Biol. Conserv. 2015, 192, 258-267. [CrossRef]

25. Rubio, A.V.; Fredes, F.; Simonetti, J.A. Exotic Pinus radiata plantations do not increase Andes Hantavirus prevalence in rodents. EcoHealth 2019, 16, 659-670. [CrossRef]

26. Ebensperger, L.A.; Mella, J.E.; Simonetti, J.A. Trophic-niche relationships among Galictis cuja, Dusicyon culpaeus, and Tyto alba in central Chile. J. Mammal. 1991, 72, 820-823. [CrossRef]

27. Yensen, E.; Tarifa, T. Galictis cuja. Mamm. Species 2003, 2003, 1-8. [CrossRef]

28. Delibes, M.; Travaini, A.; Zapata, S.C.; Palomares, F. Alien mammals and the trophic position of the lesser grison (Galictis cuja) in Argentinean Patagonia. Can. J. Zool. 2003, 81, 157-162. [CrossRef]

29. Sade, S.; Rau, J.R.; Orellana, J.I. Dieta del quique (Galictis cuja Molina 1782) en un remanente de bosque valdiviano fragmentado del sur de Chile. Gayana 2012, 76, 112-116. (In Spanish) [CrossRef]

30. Kasper, C.B.; Peters, F.B.; Christoff, A.U.; de Freitas, T.R.O. Trophic relationships of sympatric small carnivores in fragmented landscapes of southern Brazil: Niche overlap and potential for competition. Mammalia 2016, 80, 143-152. [CrossRef]

31. Luengos Vidal, E.M.; Castillo, D.F.; Caruso, N.C.; Casanave, E.B.; Lucherini, M. Field capture, chemical immobilization, and morphometrics of a little-studied South American carnivore, the lesser grison. Wild. Soc. Bull. 2016, 40, 400-405. [CrossRef]

32. Cantoni, G.; Padula, P.; Calderón, G.; Mills, J.; Herrero, E.; Sandoval, P.; Martinez, V.; Pini, N.; Larrieu, E. Seasonal variation in prevalence of antibody to hantaviruses in rodents from southern Argentina. Trop. Med. Int. Health 2001, 6, 811-816. [CrossRef]

33. Saavedra, B.; Simonetti, J.A. Small mammals of Maulino forest remnants, a vanishing ecosystem of south-central Chile. Mammalia 2005, 69, 337-348. [CrossRef]

34. González-Ittig, R.E.; Salazar-Bravo, J.; Barquez, R.M.; Gardenal, C.N. Phylogenetic relationships among species of the genus Oligoryzomys (Rodentia, Cricetidae) from Central and South America. Zool. Scr. 2010, 39, 511-526. [CrossRef] 
35. Lima, S.L.; Bednekoff, P.A. Temporal Variation in Danger Drives Antipredator Behavior: The Predation Risk Allocation Hypothesis. Am. Nat. 1999, 153, 649-659. [CrossRef] [PubMed]

36. Coldwell, V. An Analysis of Methodologies Used to Study Medium and Large Mammals in the Valdivian Temperate Rainforests of Central-Southern Chile; Imperial College: London, UK, 2008.

37. Galvez, N. Priority Habitats for Carnivores Surrounding Protected Areas in Andean Temperate Forests of Chile; University of Kent: Canterbury, UK, 2009.

38. Murúa, R.; González, L.; Meserve, P. Population ecology of Oryzomys longicaudatus philippii (Rodentia: Cricetidae) in southern Chile. J. Anim. Ecol. 1986, 281-293. [CrossRef]

39. Polop, F.; Levis, S.; Pini, N.; Enría, D.; Polop, J.; Provensal, M.C. Factors associated with hantavirus infection in a wild host rodent from Cholila, Chubut Province, Argentina. Mammal. Biol. 2018, 88, 107-113. [CrossRef]

40. Polop, F.J.; Provensal, M.C.; Pini, N.; Levis, S.C.; Priotto, J.W.; Enría, D.; Calderón, G.E.; Costa, F.; Polop, J.J. Temporal and spatial host abundance and prevalence of Andes hantavirus in southern Argentina. EcoHealth 2010, 7, 176-184. [CrossRef] [PubMed]

41. Quintana, V.; Yáñez, J.; Valdebenito, M.; Iriarte, A. Orden carnívora. In Mamíferos de Chile; Pedreros, A.M., Yañez, J., Eds.; Ediciones CEA: Valdivia, Chile, 2000. (In Spanish)

42. Apfelbach, R.; Blanchard, C.D.; Blanchard, R.J.; Hayes, R.A.; McGregor, I.S. The effects of predator odors in mammalian prey species: A review of field and laboratory studies. Neurosci. Biobehav. Rev. 2005, 29, 1123-1144. [CrossRef] [PubMed]

43. Navarro-Castilla, Á.; Barja, I. Does predation risk, through moon phase and predator cues, modulate food intake, antipredatory and physiological responses in wood mice (Apodemus sylvaticus)? Behav. Ecol. Sociobiol. 2014, 68, 1505-1512. [CrossRef]

44. Barja, I.; Silvan, G.; Illera, J.C. Relationships between sex and stress hormone levels in feces and marking behavior in a wild population of Iberian wolves (Canis lupus signatus). J. Chem. Ecol. 2008, 34, 697-701. [CrossRef]

45. Barja, I.; Silvan, G.; Martinez-Fernandez, L.; Illera, J.C. Physiological stress responses, fecal marking behavior, and reproduction in wild European pine martens (Martes martes). J. Chem. Ecol. 2011, 37, 253-259. [CrossRef] [PubMed]

46. Hayes, R.A.; Morelli, T.L.; Wright, P.C. Volatile components of lemur scent secretions vary throughout the year. Am. J. Primatol. 2006, 68, 1202-1207. [CrossRef] [PubMed]

47. Scordato, E.S.; Dubay, G.; Drea, C.M. Chemical composition of scent marks in the ringtailed lemur (Lemur catta): Glandular differences, seasonal variation, and individual signatures. Chem. Senses 2007, 32, 493-504. [CrossRef]

48. Martín, J.; Barja, I.; López, P. Chemical scent constituents in feces of wild Iberian wolves (Canis lupus signatus). Biochem. Syst. Ecol. 2010, 38, 1096-1102. [CrossRef]

49. Navarro-Castilla, Á.; Barja, I. Stressful living in lower-quality habitats? Body mass, feeding behavior and physiological stress levels in wild wood mouse populations. Integr. Zool. 2019, 14, 114-126. [CrossRef] [PubMed]

50. Barja, I.; Escribano-Ávila, G.; Lara-Romero, C.; Virgós, E.; Benito, J.; Rafart, E. Non-invasive monitoring of adrenocortical activity in European badgers (Meles meles) and effects of sample collection and storage on faecal cortisol metabolite concentrations. Anim. Biol. 2012, 62, 419-432. [CrossRef]

51. Woodruff, J.A.; Lacey, E.A.; Bentley, G.E.; Kriegsfeld, L.J. Effects of social environment on baseline glucocorticoid levels in a communally breeding rodent, the colonial tuco-tuco (Ctenomys sociabilis). Horm. Behav. 2013, 64, 566-572. [CrossRef] [PubMed]

52. Sanchez-Gonzalez, B.; Barja, I.; Pineiro, A.; Hernandez-Gonzalez, M.C.; Silvan, G.; Illera, J.C.; Latorre, R. Support vector machines for explaining physiological stress response in Wood mice (Apodemus sylvaticus). Sci. Rep. 2018, 8, 2562. [CrossRef] [PubMed]

53. Touma, C.; Sachser, N.; Möstl, E.; Palme, R. Effects of sex and time of day on metabolism and excretion of corticosterone in urine and feces of mice. Gen. Comp. Endocrinol. 2003, 130, 267-278. [CrossRef]

54. Navarro-Castilla, Á.; Barja, I. Antipredatory response and food intake in wood mice (Apodemus sylvaticus) under simulated predation risk by resident and novel carnivorous predators. Ethology 2014, 120, 90-98. [CrossRef]

55. Brzeziński, M.; Pyrlik, J.; Churski, M.; Komar, E.; Zalewski, A. The influence of American mink odour on the spatial distribution and behaviour of water voles. Ethology 2019, 125, 791-801. [CrossRef]

56. Navarro-Castilla, Á.; Sánchez-González, B.; Barja, I. Latrine behaviour and faecal corticosterone metabolites as indicators of habitat-related responses of wild rabbits to predation risk. Ecol. Indic. 2019, 97, 175-182. [CrossRef]

57. Fishman, M.A. Predator inspection: Closer approach as a way to improve assessment of potential threats. J. Theor. Biol. 1999, 196, 225-235. [CrossRef] [PubMed]

58. Fincel, M.; Chipps, S.; Voldseth, R. Chemically-mediated predator inspection behavior by fathead minnow (Pimephales promelas). J. Freshwr. Ecol. 2010, 25, 279-283. [CrossRef]

59. Soares, M.C.; Bshary, R.; Cardoso, S.C.; Côté, I.M.; Oliveira, R.F. Face your fears: Cleaning gobies inspect predators despite being stressed by them. PLoS ONE 2012, 7, e39781. [CrossRef]

60. Nolte, D.L.; Mason, J.R.; Epple, G.; Aronov, E.; Campbell, D.L. Why are predator urines aversive to prey? J. Chem. Ecol. 1994, 20, 1505-1516. [CrossRef] [PubMed]

61. Berton, F.; Vogel, E.; Belzung, C. Modulation of mice anxiety in response to cat odor as a consequence of predators diet. Physiol. Behav. 1998, 65, 247-254. [CrossRef]

62. Kats, L.B.; Dill, L.M. The scent of death: Chemosensory assessment of predation risk by prey animals. Écoscience 1998, 5, 361-394. [CrossRef]

63. Murray, D.L.; Jenkins, C.L. Perceived predation risk as a function of predator dietary cues in terrestrial salamanders. Anim. Behav. 1999, 57, 33-39. [CrossRef] 
64. Dickman, C.R.; Doncaster, C.P. Responses of small mammals to Red fox (Vulpes vulpes) odour. J. Zool. 1984, $204,521-531$. [CrossRef]

65. Dickman, C.R. Predation and Habitat Shift in the House Mouse Mus Domesticus. Ecology 1992, 73, 313-322. [CrossRef]

66. Zapata, S.C.; Travaini, A.; Delibes, M.; Martínez-Peck, R. Annual food habits of the lesser grison (Galictis cuja) at the southern limit of its range. Mammalia 2005, 69, 85-88. [CrossRef]

67. Cowan, P. Neophobia and neophilia: New-object and new-place reactions of three Rattus species. J. Comp. Physiol. Psychol. 1977, 91, 63-71. [CrossRef]

68. Barnett, S.A. Exploring, sampling, neophobia, and feeding. In Rodent Pest Management; Prakash, I., Ed.; CRC Press: Boca Raton, FL, USA, 1988.

69. Best, I.N.; Shaner, P.L.; Lo, H.Y.; Pei, K.J.; Kuo, C.C. Bigger doesn't mean bolder: Behavioral variation of four wild rodent species to novelty and predation risk following a fast-slow continuum. Front. Zool. 2020, 17, 27. [CrossRef]

70. Figueroa, R.; Corales, S.; Cerda, J.; Saldivia, H. Roedores, Rapaces y Carnívoros de Aysén; Servicio Agrícola y Ganadero, Gobierno Regional de Aysén: Coyhaique, Chile, 2001. (In Spanish)

71. Hernández, M.C.; Jara-Stapfer, D.M.; Muñoz, A.; Bonacic, C.; Barja, I.; Rubio, A.V. Behavioral Responses of Wild Rodents to Owl Calls in an Austral Temperate Forest. Animals 2021, 11, 428. [CrossRef]

72. Vasquez, R.A. Patch utilization by three species of Chilean rodents differing in body size and mode of locomotion. Ecology 1996, 77, 2343-2351. [CrossRef]

73. Moore, Y.T. An Integrative Investigation of Convergent Bipedal Locomotion in Desert Rodents; Harvard University: Cambridge, MA, USA, 2016.

74. Ylönen, H.; Eccard, J.A.; Jokinen, I.; Sundell, J. Is the antipredatory response in behaviour reflected in stress measured in faecal corticosteroids in a small rodent? Behav. Ecol. Sociobiol. 2006, 60, 350-358. [CrossRef]

75. Boonstra, R.; Hik, D.; Singleton, G.R.; Tinnikov, A. The Impact of Predator-Induced Stress on the Snowshoe Hare Cycle. Ecol. Monog. 1998, 68, 371-394. [CrossRef]

76. Sheriff, M.J.; Thaler, J.S. Ecophysiological effects of predation risk; an integration across disciplines. Oecologia 2014, 176, 607-611. [CrossRef]

77. Hammerschlag, N.; Meÿer, M.; Seakamela, S.M.; Kirkman, S.; Fallows, C.; Creel, S. Physiological stress responses to natural variation in predation risk: Evidence from white sharks and seals. Ecology 2017, 98, 3199-3210. [CrossRef] [PubMed]

78. Gyssels, F.G.M.; Stoks, R. Threat-Sensitive Responses to Predator Attacks in a Damselfly. Ethology 2005, 111, 411-423. [CrossRef]

79. MacLean, S.A.; Bonter, D.N. The sound of danger: Threat sensitivity to predator vocalizations, alarm calls, and novelty in gulls. PLoS ONE 2013, 8, e82384. [CrossRef] [PubMed]

80. Monclús, R.; Palomares, F.; Tablado, Z.; Martínez-Fontúrbel, A.; Palme, R. Testing the threat-sensitive predator avoidance hypothesis: Physiological responses and predator pressure in wild rabbits. Oecologia 2009, 158, 615-623. [CrossRef] [PubMed]

81. Parker, G.A.; Smith, J.M. Optimality theory in evolutionary biology. Nature 1990, 348, 27-33. [CrossRef]

82. Orzack, S.H.; Sober, E. Optimality models and the test of adaptationism. Am. Nat. 1994, 143, 361-380. [CrossRef]

83. Rosen, R. Optimality Principles in Biology; Springer: Berlin/Heidelberg, Germany, 2013. 